University of Nebraska - Lincoln

DigitalCommons@University of Nebraska - Lincoln

Roman L. Hruska U.S. Meat Animal Research

U.S. Department of Agriculture: Agricultural Center

Research Service, Lincoln, Nebraska

1988

Relationship of Growth Hormone, Prolactin, and Thyrotropin Secretion to Individual and Progeny Performance of Hereford Bulls

\author{
Danny L. Ohlson \\ U.S. Meat Animal Research Center \\ Robert M. Koch \\ U.S. Meat Animal Research Center \\ John Klindt \\ U.S. Meat Animal Research Center \\ Steven L. Davis \\ Oregon State University
}

Follow this and additional works at: https://digitalcommons.unl.edu/hruskareports

Part of the Animal Sciences Commons

Ohlson, Danny L.; Koch, Robert M.; Klindt, John; and Davis, Steven L., "Relationship of Growth Hormone, Prolactin, and Thyrotropin Secretion to Individual and Progeny Performance of Hereford Bulls" (1988). Roman L. Hruska U.S. Meat Animal Research Center. 100.

https://digitalcommons.unl.edu/hruskareports/100

This Article is brought to you for free and open access by the U.S. Department of Agriculture: Agricultural Research Service, Lincoln, Nebraska at DigitalCommons@University of Nebraska - Lincoln. It has been accepted for inclusion in Roman L. Hruska U.S. Meat Animal Research Center by an authorized administrator of DigitalCommons@University of Nebraska - Lincoln. 


\section{Relationship of Growth Hormone, Prolactin, and Thyrotropin Secretion to Individual and Progeny Performance of Hereford Bulls}

Danny L. Ohlson, Robert M. Koch, John Klindt, and Steven L. Davis ${ }^{1,2}$

\section{Introduction}

Evidence from several studies has supported a predictive relationship between measures of somatotropic hormones and genetically determined growth potential in domestic ruminants. In these studies, blood concentrations of hormones associated with growth were generally higher in lines or breeds with greater growth potential. However, no significant positive correlations between measures of hormone secretion and measures of growth in individual animals were observed.

The present study further assesses the association between growth potential, growth rate, and secretion of growth hormone $(\mathrm{GH})$, prolactin (PRL), and thyrotropin (TSH) using bulls of two Hereford lines that differ in growth rate as a result of genetic selection. The objectives of this study were (1) to compare blood levels of $\mathrm{GH}$, $\mathrm{PRL}$, and TSH between the two lines of bulls, and (2) to evaluate the predictive value of sire hormone data for growth rate of their progeny.

\section{Procedure}

Animals were representatives of Hereford lines established in 1960 to investigate response to mass selection in traits of economic importance in beef cattle. Briefly, three lines of Herefords were established at the Fort Robinson Beef Cattle Research Station, Crawford, Nebraska, and maintained there through 1971. Selection in one line was practiced for 200-day wt adjusted for age of dam. Adjusted final wt, at 424 days for bulls and 500 days for heifers, was the selection criterion in the second line. Selection based on an index giving equal emphasis to adjusted final wt and muscling score was used for the third line (index line). Muscling score was a measure of thickness of forearm, loin, rump, and round, with degree of fatness discounted. After 1971, a non-selected control line was established using foundation animals.

After the 1982 breeding season, six bulls from the control line and six bulls from the index line were placed in individual stanchions and fed ad libitum a diet of corn silage and high moisture corn for $3 \mathrm{wk}$. The photoperiod was 16 hr light: 8 hr dark, starting at 6 a.m. After this adaptation period, a jugular cannula was inserted into each bull for blood sampling. The next day, 10-ml blood samples were collected into heparinized vacutainers at 15-min intervals for $8 \mathrm{hr}$, beginning at 8:30 a.m. Samples

'Ohlson was a research associate, Meats Unit, MARC; Koch is a professor of animal science, University of NebraskaLincoln, stationed at MARC; Klindt is a research physiologist, Meats Unit, MARC; and Davis is the animal science department head, Oregon State University.

${ }^{2}$ The full report of this work was published in J. Anim. Sci. 65:63-67, 1987. were chilled on ice during collection, stored overnight at $39^{\circ} \mathrm{F}$, and plasma was harvested and stored at $-4^{\circ} \mathrm{F}$ until assayed. The bulls in this study were 2 and 3 yr of age when the blood samples were drawn.

Plasma concentrations of $\mathrm{GH}, \mathrm{PRL}$, and $\mathrm{TSH}$ were determined by radioimmunoassay. Mean overall concentration (Mn 33 observations), mean baseline concentration (BI), spike amplitude (Am, magnitude of secretory spike above baseline), and spike frequency (Pk) were calculated for each hormone in each bull.

\section{Results}

Bulls representing the index line were heavier at birth $(\mathrm{P}<.02)$ and gained at a faster rate postweaning $(\mathrm{P}<.01)$ than bulls representing the control line. Also, the progeny of sires from the index line were heavier at birth and gained more rapidly from birth to weaning and postweaning (all $\mathrm{P}<.001$ ) than progeny from control line sires.

Overall mean concentrations of $\mathrm{GH}$ were higher $(\mathrm{P}<.03)$, and overall and baseline concentrations of $P R L$ tended to be higher $(\mathrm{P}<.07, \mathrm{P}<.08)$ in index compared with control bulls. Other measures of hormone secretion did not differ significantly between lines, but were, in each instance, higher in index bulls than in control bulls.

Individual performance of parents was the basis of selection in the experiment. The three types of selection imposed were effective in making slow but significant changes in growth rate. The characteristics of GH, PRL, and TSH (Mn, BI, Pk, and Am) accounted for significant amounts of variation in birth wt and postweaning daily gain of progeny and, when combined with sire growth rate, increased the accuracy of prediction of progeny performance.

Although meaningful interpretation of the individual partial regression coefficients is not possible in these data, the results indicate that measures of hormone secretion may have value for predicting the expected growth response of progeny. Presumably, useful prediction equations could be obtained from hormone profiles on larger numbers of sires and their progeny. Perhaps more than one "window" of hormone secretory activity should be monitored. Also, monitoring at different stages of the growth cycle should be investigated to determine the optimal time or times for accurate prediction of progeny performance. Results of the present study support those of earlier research comparing Hereford and Simmental bull calves and comparing two lines of Targhee rams. Members of a breed or line with the genetic potential for faster growth or larger mature size exhibit some significantly elevated characteristics of hormone secretion (GH and PRL in Simmentals and GH and TSH in selected rams) when compared with animals with less genetic potential for growth rate and mature size. 